\title{
ASSESMENT PERENCANAAN PEMBELAJARAN GURU DI SMA NURUL MUTTAQIN ALBAROKHAH KOTA MALANG
}

\author{
Wiwin Ni'maturrohmah \\ Universitas Negeri Malang \\ nimaturwiwin@gmail.com
}

\begin{abstract}
Learning planning is the first step that teachers must prepare before teaching. This study method uses qualitative, with the subject of teacher research in SMA Nurul Muttaqin Albarokhab Malang. The results of this study indicate that teachers at

Received: SMA Nurul Muttaqin Albarokhah Malang always prepare learning tools, March 23 2020 materials, strategies / methods, media, evaluation of learning, and mentality in the teaching process. Stages in the preparation of planning teaching materials are carried Revised: out by preparing learning tools, preparing and choosing methods, strategies, media, April $07^{\text {th }} 2020$ and class assessments, as well as looking for materials by looking at the grade level / abilities of students. The constraints found in the planning process are influenced by May $27^{\text {th }} 2020$ students, teachers, and the limited facilities and infrastructure at the school.

Keywords: Assesment, Learning planning, SMA
\end{abstract}

\section{PENDAHULUAN}

Untuk mewujudkan pendidikan yang bermutu, salah satu langkah yang dilakukan oleh guru adalah melakukan perencanaan pembelajaran. Dalam kontek ini, yang dimaksud dengan rencana pembelajaran (lesson plan) merupakan perencanaan yang dibuat guru sebelum melakukan proses belajar mengajar ${ }^{1}$. Oleh karena itu, maka perencanaan pembelajaran merupakan langkah awal untuk menentukan cara yang paling efektif dan efisien dalam proses belajar mengajar ${ }^{2}$ dengan cara memilih, menetapkan, dan mengembangkan metode untuk mencapai hasil pembelajaran yang di inginkan³.

Dalam lesson plan ini, guru membuat proyeksi yang akan dilakukan dalam proses belajar mengajar ${ }^{4}$ untuk mencapai penilaian yang bernilai ${ }^{5}$. Adapun proyeksi yang dilakukan guru diantaranya adalah proses penyusunan materi pelajaran, penggunaan media, pendekatan dan metode, serta penilaian pembelajaran dalam suatu alokasi waktu yang akan dilaksanakan pada masa tertentu untuk mencapai tujuan yang telah ditentukan ${ }^{6}$.

\footnotetext{
${ }^{1}$ M Chatib, Sekolahnya Manusia: Sekolah Berbasis Multiple Intelligences Di Indonesia (Bandung: Mizan Pustaka, 2009).

2 Harjanto, Perencanaan Pengajaran (Jakarta: Rineka Cipta, 2003).

${ }^{3}$ Hamzah B Uno, Model Pembelajaran Menciptakan Proses Belajar Mengajar Yang Kreatif Dan Efektif (Jakarta: Bumi Aksara,

${ }^{4}$ Mustofa Ali. dkk., Bahan Ajar Perencanaan Pembelajaran (Surabaya: Kopertais IV Press, 2010).

${ }^{5}$ Harjanto, Perencanaan Pengajaran.

${ }^{6}$ Abdul Majid, Perencanaan Pembelajaran, (Bandung: Remaja Rosdakarya, 2012).
} 2007). 
Enoch mengungkapkan bahwa perencanaan merupakan suatu proses berlangsung sepanjang waktu dan berulang kembali membentuk suatu lingkaran (siklus) ${ }^{7}$. Hal ini juga berlaku pada proses perencanaan pembelajaran, yakni berbentuk siklus atau lingkaran kegiatan perencanaan yang berjalan sepanjang waktu dan berulang kali ${ }^{8}$. Oleh karena itu, maka dalam penelitian ini penulis akan mengkaji tentang Assesment perencanaan pembelajaran guru di SMA Nurul Muttaqin Albarokhah Kota Malang.

\section{METODE}

Studi ini dilakukan dengan metode penelitian kualitatif. Tempat penelitian SMA Nurul Muttaqin Albarokhah Kelurahan Tlogowaru, Kecamatan Kedungkandang, Kota Malang dengan sumber data dari Guru tetap di sekolah tersebut. Teknik pengumpulan data dengan teknik observasi, interview dan dokumentasi. Untuk teknik analisis data dilakukan dengan tahap-tahap pengumpulan data, reduksi data, dan penyajian data penelitian.

\section{PENYAJIAN DAN PEMBAHASAN DATA}

SMA Nurul Muttaqin Albarokhah adalah lembaga pendidikan yang berlokasi JL. Nurul Muttaqin 39 Kelurahan Tlogowaru, Kecamatan Kedungkandang, Kota Malang. Sekolah yang memiliki berdiri di tahun 2013 dengan nomor izin operasional: 421.8/7833/.5.73.307/2014, dan NPSN: 69849409 ini telah menerapkan kurikulum 2013.

\section{Persiapan Sebelum Mengajar Guru SMA Nurul Muttaqin Albarokhah}

Lesson plan di kelas merupakan langkah awal yang dilakukan guru agar materi pelajaran yang disampaikan kepada siswa dapat tersampaikan dengan baik. Hasil studi lapangan di SMA Nurul Muttaqin Albarokhah menunjukkan bahwa guru di sekolah tersebut sebelum melakukan pengajaran telah mempersiapkan berbagai perencanaan, diantaranya:

\section{Perangkat Pembelajaran.}

guru SMA Nurul Muttaqin Albarokhah telah membuat dan mempersiapkan perangkat pembelajaran yang diperlukan, diantaranya silabus, RPP, Prota (Program Tahunan), Promes (Program Semester), buku pedoman guru atau buku panduan guru, buku pendukung, jurnal materi. Dengan jumlah TDK yang tidak banyak, maka koordinasi antar guru di sekolah tersebut relatif lebih mudah, sehingga kekompakan antar guru untuk menyiapkan perangkat pembelajaran tidak menjadi kendala yang besar di sekolah tersebut.

${ }^{7}$ Jusuf Enoch, Dasar-Dasar Perencanaan Pendidikan (Jakarta: Bumi Aksara, 1995).

${ }_{8}^{8}$ Djumberansyah Indar, Perencanaan Pendidikan Strategi Dan Implementasinya (Jakarta: Karya Abditama, 1995). 


\section{Strategi/metode, Materi, Media, dan Evaluasi Pembelajaran.}

Guru SMA Nurul Muttaqin Albarokhah juga telah membuat perencanaan tentang Strategi dan materi yang akan disampaikan di kelas. Selain itu, guru di sekolah tersebut juga memilih dan mendesain media yang cocok untuk digunakan dalam proses pembelajaran, serta telah dilengkapi dengan evaluasi pembelajaran untuk mengetahui diketahui efektifitas proses pembelajaran yang akan dilakukan.

\section{Semangat Mengajar.}

Selain mempersiapkan perangkat pembelajaran, dan strategi, materi, media, dan evaluasi pembelajaran di atas, para guru juga menambah faktor semangat untuk mendidik anak-anak mereka dengan baik. Walaupun kondisi sarana dan prasarana yang terbatas, mereka tetap menjaga spirit mereka agar dalam lesson plan mereka tetap dilakukan yang terbaik.

\section{Perencanaan Materi Pengajaran}

Perencanaan materi pengajaran guru SMA Nurul Muttaqin Albarokhah dilakukan melalui beberapa tahap. Pertama, Guru melakukan perencanaan materi dengan menyesuaikan RPP yang sudah dirancang dalam persiapan pembelajaran. Hal ini selaras dengan pernyataan Khusnul Khotimah sebagai berikut

Adanya kompetensi inti dan dilanjutkan dengan kompetensi dasarnya, dari KI dan KD dikembangkan melalui RPP. Contoh: tema tentang keimanan terhadap Allah melalui asmaul husna yang sudah dibaca oleh murid, maka murid memahami, mampu menyebutkan dan menjelaskan tentang asmaul husna.

Selain melakukan penyelarasan, guru di SMA Nurul Muttaqin Albarokhah juga terus mengkaji ulang materi dan melakukan penyempurnaan materi yang telah dibuat sebelumnya. Mereka juga melakukan pendalaman materi baik melalui buku maupun memanfaatkan sumber materi di internet. Mereka juga merencanakan strategi apa yang akan diimplementasikan dalam penyampaian materi kepada para siswa mereka sesuai dengan kondisi dan karakteristik siswa yang dihadapinya. Sebagaimana diungkapkan Wahyu Ludina berikut ini:

... yaitu dengan cara menyiapakan beberapa metode yang akan digunakan sesuai dengan kondisi kelas anak didik. Menyiapkan materi yang akan diajarkan juga melibat keadaan kelas juga karena tingkat intelektualnya tidak sama. Guru tersebut selalu belajar akan materi yang akan diajarkannya besok dengan sunggub-sungguh dan cermat, karena di era globalisasi ini anak-anak sudah banyak yang pandai, mereka mencari-cari materi pelajaran mereka, terkadang ada siswa yang lebih pandai daripada gurunya. Guru tersebut juga selalu membawa laptop dan modem, untuk. menanggulangi hal-hal yang seperti barusan. 


\section{Perencanaan dalam Pemanfaatan media Pengajaran}

Guru di SMA Nurul Muttaqin Albarokhah dari hasil studi assesment ini telah melakukan perencanaan pemanfaatan media pengajaran. Dari hasil interview, para guru dalam menyiapkan media juga telah menyesuaikan dengan RPP dengan melihat KI dan KD dari materi yang diajarkannya, sebagaimana diungkapkan oleh Siti Mudrikah dan Khusnul Khotimah sebagai berikut:

Menganalisis kebutuban dan karakteristik siswa, Merumuskan tujuan sesuai dengan KI dan KD, Merumuskan butir-butir materi secara terperinci yang mendukung tercapainya tujuan, Mengembangkan alat pengukur keberhasilan, Menulis naskah media, Mengadakan tes dan revisi.

Dan langkah-langkah itu sudah ada dalam RPP, Ada kegiatan pembukaan, kegiatan inti dan kegiatan penutup. dan untuk media di RPP itu sudah tercantum dalam kegiatan inti. Contob: Medianya menggunakan media gambar, maka gambar yang di amati anak didik itu sudah dipersiapkakn sebelum proses pembelajaran.dan media itu sesuai dengan KI dan KD.

Para guru juga mempertimbangkan dengan kebutuhan dan karakteristik siswanya, sehingga materi yang akan disampaikan melalui media tersebut dapat digunakan secara maksimal.

Para guru di sekolah tersebut sangat menyadari bahwa media memiliki peran strategis agar materi yang disampaikan dapat diterima dengan baik. Pemilihan bentuk media juga menjadi pertimbangan dengan memanfaatkan fasilitas di sekolah, khususnya LCD/Infokus, sehingga guru dapat memanfaatkan dan mengembangkan media elektronik secara lebih leluasa. Misalnya dengan memanfaatkan media yang berbasis audio visual, atau visual saja, sebagaimana ungkapan Khusnul Khotimah.

Media itu sangat mendukung dalam proses pembelajaran, karena ketika anak didik menggunakan audio saja tanpa visual maka anak-anak mengalami kekurangan daya tangkapnya, akan tetapi jika menggunakan audio visual maka anak didik lebih peka dalam menangkap materi yang disampaikan.

Dengan memanfaatkan LCD, para guru juga mendorong siswa-siswinya untuk memanfaatkan media yang telah disiapkan dengan membuat power point. Sehingga siswa juga memiliki ketrampilan yang cukup dalam memaparkan materi-materi yang yang telah mereka siapkan, sebagaimana hasil interview dengan Wahyu Ludina sebagai berikut:

yaitu biasanya jauh-jauh hari guru tersebut memberi tugas kepada siswa untuk membuat power point terkait dengan materi pelajaran, power poin yang terbaik dan terlengkap untuk dibuat belajar, akan guru tersebut tampilkan dengan lcd proyektor di kelas, guru tersebut memilib untuk merencanakan pembelajaran seperti itu dengan alasan, yang pertama siswa pasti akan berusaha mencari materi yang akan disampaikan tanpa menunggu dari guru daja, kedua karena siswa melibat dan mendengar lebih banyak yang ditangkap yaitu dengan melibat. jadi waktu guru menerangkan siswa juga sambil bisa melihat materi atapun gambar pelajaran di lcd supaya ingat.

Walaupun begitu, mereka juga memiliki fleksibelitas dalam memanfaatkan media, apabila di sekolah terdapat kekurangan fasilitas, sebagaimana pernyataan responden sebagai berikut: "Guru harus bisa menggunakan media yang di sediakan dari sekolah kalau tidak ada maka cukup menggunakan buku saja.” 


\section{Kendala-kendala dalam Perencanaan Pembelajaran}

Dalam implementasi perencanaan, para guru di SMA juga mengalami beragam kendala, diantaranya: Kendala dari Peserta Didik, pendidik dan sarana prasarana sekolah.

Pertama, kendala dari peserta didik. Kendala dari peserta didik yang dihadapi oleh guru diantaranya karena beragamnya kompetensi peserta didik. Kondisi ini berpengaruh kepada beragamnya mentalitas dan kreatifitas yang dimiliki peserta didik, sehingga daya tanggap materi yang disampaikan oleh guru juga menjadi berbeda antara siswa satu dengan lainnya. Selain itu, persiapan mental untuk belajar dan peristiwa di lingkungan keluarganya juga berpengaruh kepada situasi dan kondisi di kelas, sebagaimana pernyataan Khusnul Khotimah sebagai berikut:

Ketika anak didik mungkin terbawa emosi dari rumahnya, menjadikan gaduh dan ramai, tentunya dari proses pembelajaran agak sedikit tertunda.

Persiapan untuk mempresentasikan tugas yang diberikan kepada siswa yang kurang maksimal juga menjadi kendala, walaupun tidak sering dijumpai. Misalnya materi file yang seharusnya dipresentasikan tidak terbawa oleh siswa mereka di sekolah sebagaimana diungkapkan Wahyu Ludina.

ketika siswa yang waktunya maju untuk, presentasi lupa membawa flasdisk, ketika tiba-tiba pelajaran dihentikan karena melayat,dll

Kedua, kendala dari pendidik. Dari hasil studi lapangan, tidak banyak kendala yang dihadapi oleh pendidik. Namun mereka juga mengalami beberapa kendala, diantaranya karena guru yang masih baru, sehingga mereka masih perlu beradaptasi dalam melaksanakan penyesuaian antara perencanaan dengan implementasi di lapangan.

Ketiga, Kendala dari sarana dan prasarana. Keterbatsan sarana dan prasarana juga menjadi kendala dalam menjalankan lesson plan dengan baik. Khususnya fasilitas LCD yang mengalami kerusakan atau keterlambatan karena keterbatasan LCD yang dimiliki oleh sekolah, sebagaina dituturkan oleh Andi Prita dan Khusnul Khotimah sebagai berikut:

... antara rencana dengan kondisi kelas (lapangan) tidak sesuai dengan harapan. Contoh: LCD rusak, siswa tidak siap dengan materi tersebut. ... dan juga disebabkan karena persiapan media pembelajaran seperti projector lambat.

Dari hasil penyajian data di atas, diketahui bahwa SMA Nurul Muttaqin Albarokhah Kota Malang adalah salah satu lembaga pendidikan yang mulai berkembang. Dengan fasilitas yang terbatas dan ditopang dengan SDM yang terbatas, namun mereka tetap memiliki komitmen kuat dalam mengembangkan mutu pendidikan di sekolah mereka. Hal ini terlihat dari perencanaan pembelajaran yang diterapkan di sekolah tersebut.

Secara umum, semua guru di SMA Nurul Muttaqin Albarokhah Kota Malang telah mengimplementasikan perencanaan pembelajaran dengan baik, mulai dari mempersiapkan perangkat 
pembelajaran, merencanakan materi, media, strategi dan evaluasinya. Selain itu, semangat untuk selalu meningkatkan mutu pendidikan dengan dimulai mempersiapkan lesson plan secara terencana telah dilakukan dengan baik. Namun begitu, kendala-kendala dalam implementasi lesson plan juga dihadapi oleh para guru di sekolah tersebut, diantaranya kendala yang disebabkan oleh peserta didik, kendala dari pendidik itu sendiri, maupun kendala dari keterbatasan sarana dan prasarana yang ada? .

Hasil studi ini juga menunjukkan bahwa secara umum para guru sudah melakukan perencanaan dengan baik, namun dalam implementasi di lapangan memiliki kendala yang berbeda-beda antara lembaga pendidiikan yang satu dengan lembaga pendidikan lainnya

\section{KESIMPULAN}

Dari hasil penyajian data dan pembahasan di atas, dapat disimpulkan bahwa guru di SMA Nurul Muttaqin Albarokhah Kota Malang selalu mempersiapkan perangkat pembelajaran, materi, strategi/metode, media, evaluasi pembelajaran, serta mental dalam proses pengajaran. Terkait dengan perencanaan materi pengajaran, guru di sekolah tersebut selalu merujuk dan menyesuaikan dengan RPP / perangkat pembelajaran yang sudah dirancang, mempersiapkan / memilih metode, strategi, dan merencanakan pelaksanaan penyampaian materi, menyiapkan media, mencari bahan materi dengan melihat tingkat kelas / kemampuan siswa. Untuk perencanaan pemilihan media pengajaran, guru di sekolah tersebut menyesuaikan dengan RPP serta tema materi yang disampaikan kepada peserta didik. Selain itu, para guru juha melakukan pemanfaatan media yang tersedia di sekolah. Terkait dengan kendalakendala yang ditemukan dalam proses perencanaan dipengaruhi oleh siswa, guru, dan keterbatasan sarana dan prasarana di sekolah tersebut.

\section{DAFTAR PUSTAKA}

Chatib, M. Sekolahnya Manusia: Sekolah Berbasis Multiple Intelligences Di Indonesia. Bandung: Mizan Pustaka, 2009.

Enoch, Jusuf. Dasar-Dasar Perencanaan Pendidikan. Jakarta: Bumi Aksara, 1995.

Fathurrohman, Amang, and Moh. Nurhadi. "Perencanaan Pembelajaran Guru Sekolah Dasar Dalam Materi Pendidikan Agama Islam Di Kabupaten Pasuruan.” Jurnal Ilmu Tarbiyah "At-Tajdid” 5, no. 2 (2016): 219-242.

Harjanto. Perencanaan Pengajaran. Jakarta: Rineka Cipta, 2003.

Indar, Djumberansyah. Perencanaan Pendidikan Strategi Dan Implementasinya. Jakarta: Karya Abditama, 1995.

${ }^{9}$ Amang Fathurrohman and Moh. Nurhadi, "Perencanaan Pembelajaran Guru Sekolah Dasar Dalam Materi Pendidikan Agama Islam Di Kabupaten Pasuruan," Jurnal Ilmu Tarbiyah “At-Tajdid” 5, no. 2 (2016): 219-242. 
Majid, Abdul. Perencanaan Pembelajaran,. Bandung: Remaja Rosdakarya, 2012.

Mustofa Ali. dkk. Bahan Ajar Perencanaan Pembelajaran. Surabaya: Kopertais IV Press, 2010.

Uno, Hamzah B. Model Pembelajaran Menciptakan Proses Belajar Mengajar Yang Kreatif Dan Efektif. Jakarta: Bumi Aksara, 2007. 